\title{
Marine Nematodes from the Shallow Subtidal Coast of the Adriatic Sea: Species List and Distribution
}

\author{
F. Semprucci \\ Dipartimento di Scienze della Terra, della Vita e dell'Ambiente (DiSTEVA), Università degli Studi di Urbino "Carlo Bo", \\ Località Crocicchia, 61029 Urbino, Italy \\ Correspondence should be addressed to F. Semprucci, federica.semprucci@uniurb.it
}

Received 14 September 2012; Revised 27 November 2012; Accepted 27 November 2012

Academic Editor: Rafael Riosmena-Rodríguez

Copyright (C) 2013 F. Semprucci. This is an open access article distributed under the Creative Commons Attribution License, which permits unrestricted use, distribution, and reproduction in any medium, provided the original work is properly cited.

\begin{abstract}
This study is the first attempt aiming to assess the composition and number of free-living marine nematode species on the coasts of the Marches region, Italy. A high number of putative species of nematodes were recognized (84), these belonging to 52 genera in 22 families. Fifty-one taxa have been identified to the species level increasing the number of known nematode species for the Adriatic Sea from 283 to 310 and for the Mediterranean Sea from 700 to 723 . The highest diversity and abundance were registered for the nematode families typically of intertidal zones characterized as medium-fine sands. The majority of the species found in the present study are known to occur in the North European coasts or the North Atlantic Sea, the best known regions for nematode distribution. Inferences on the biogeography of marine nematodes are preliminary since most Biodiversity literature concerning the Mediterranean of the basin is very out of date. Considering the great importance of nematodes in the assessment of ecosystem health conditions, an intensification of sampling efforts should be pursued in other regions in order to improve our current knowledge of the distribution pattern of marine nematode species as well as clarify their biogeographical patterns.
\end{abstract}

\section{Introduction}

Marine nematodes are the most abundant metazoans in marine sediments, reaching densities as high as 20 million individuals per square meter [1]. They generally are the dominant component of the meiofauna in any aquatic habitat, often one order of magnitude higher than any other major taxon [1]. Estimates of global nematode species diversity have significantly varied over the past 15 years, but with a growing agreement suggesting about one million species $[2,3]$. Their great importance in marine ecology as bioindicators is well recognized $[4,5]$. The study of nematode communities offers several advantages for assessing the quality of freshwater, marine, and terrestrial ecosystems. These organisms show great diversity and abundance which make easier their sampling; they present different trophic groups as well as being intimately related with their environment, the sediment. Therefore, they can provide important information on the ecological state of a given area once they are exposed to pollutants. Furthermore, they have been recently proposed within the Water Framework Directive (WFD, Directive
2000/60/EC) [6] as a tool for evaluating the ecological quality status of marine vulnerable ecosystems.

The taxonomy of marine nematodes is known to be very difficult (see for review [7]), in part due to their high diversity. Identification of nematodes at specific level is often hampered by the fact that a significant proportion of the specimens collected are juveniles or females, which often lack the diagnostic features required for an accurate identification. When males are encountered, it may be necessary to examine a high number of specimens before a final decision can be made. Owing to these limitations, biodiversity studies focusing on marine nematodes have been frequently replaced by ecological studies where identification is mostly limited to the genus level (or more rarely morphotypes). Unfortunately, this kind of information may be hardly used to create a map of distribution of the free-living marine nematodes.

A recent review of the state of knowledge of the meiofauna in the Adriatic sea has been carried out by Balsamo et al. [8]. Marine nematodes known in the Italian seas represent 443 species which are distributed into 262 genera and 46 families [9]; these are a quarter of the species reported for the 
European sea waters. Although these data are an important base line for the area, most of these records are the result of old surveys, mainly carried out in the first part of the XX century [9]. In particular, the Adriatic coast poses a high number of nematode species: 283 species in the entire Adriatic Basin and 263 in the Italian coasts (see [8] for review). Extensive investigations in this area were carried out by Allgén [10], Schuurmans-Stekhoven [11], Gerlach [12], and Travizi and Vidaković [13]. Most of the species were recorded in the area of the river Po, Venice lagoon, and Gulf of Trieste [13-15]. A significant contribution to the knowledge of marine nematodes for the southern Adriatic Basin, in particular the Apulian littoral, was provided by De Zio [16, 17] and Grimaldi-De Zio [18-20]. Therefore, most of the investigations on nematodes have been limited to the North Adriatic sector whereas from the coast of EmiliaRomagna to Apulia few studies were carried out $[9,13]$.

Despite their great ecological importance [6], the knowledge of the nematodes in the Adriatic has changed a little, except for data reported by some ecological studies where nematode identification is mostly limited to the genus level [21-26].

In this context, a nematode survey in the coastline between Fiorenzuola and Pesaro (Marches region) has been carried out. Currently, there is no data available on nematode diversity for this area as well as in the Marches region. Furthermore, this coast includes the Natural Regional Park of Monte San Bartolo, an area of high naturalistic value. Thus, the goal of the present study was to assess nematode biodiversity along this coastal area as well as to identify patterns of species distribution.

\section{Materials and Methods}

2.1. Study Area and Sampling Sites. The Adriatic sea is an elongated NW/SE oriented basin located in the central Mediterranean Sea and characterized by the most extensive development of continental shelf in the Mediterranean. It is a relatively shallow basin, especially in the northern sector, with an average water depth of $35 \mathrm{~m}$. The general circulation is cyclonic, with a flow towards the northwest along the eastern side and a return flow towards the southeast along the western side [27]. The central and southern regions of the Adriatic Sea are characterized by a low primary productivity, with the continental inputs and the benthic-pelagic interactions being of minor importance in comparison to the northern area [28].

The investigated area is located in the northern part of the Marches region (Italy) and extends from Fiorenzuola di Focara to Pesaro (Figure 1).

The nematode species reported in the present study were collected in three different sites from the sublittoral zone of the Marches coast: Fiorenzuola di Focara (FI) $\left(43^{\circ} 57^{\prime} \mathrm{N}-\right.$ $\left.12^{\circ} 49^{\prime} \mathrm{E}\right)$, Monte Brisighella (BR) $\left(43^{\circ} 56^{\prime} \mathrm{N}-12^{\circ} 50^{\prime} \mathrm{E}\right)$, and Pesaro (P) $\left(43^{\circ} 55^{\prime} \mathrm{N}-12^{\circ} 53^{\prime} \mathrm{E}\right)$ (Figure 1). In each site, two stations were established ( 1 and $3 \mathrm{~m}$ of depth) and sediment samples collected in May and November 2003. In addition, a third station was established at FI site (12 $\mathrm{m}$ in depth) which was sampled in May, July, and October 2002. The total of the samples studied for the taxonomical study of the nematodes were 15.

2.2. Sample Processing. Bulk sublittoral samples were taken using a $1.5 \mathrm{~L}$ plastic scoop digging it directly into the sediment at shallow sites and using a Van Veen grab at the deeper sites ( 3 and $12 \mathrm{~m}$ ). Nematode samples were first fixed in a $7 \%$ magnesium chloride aqueous solution and then posteriorly using a $4 \%$ formaldehyde solution (in a buffered sea-water). Two additional samples were taken to determinate the sedimentological features as well as total organic content of each site, depth, and period.

2.3. Abiotic Parameters. Grain size analysis was performed on the collected samples using a vibrosiever for fractions larger than $63 \mu \mathrm{m}$ and an X-ray analyzer for those smaller than $63 \mu \mathrm{m}$. Sediments were classified following the Wentworth scale [29].

Total organic matter content was gravimetrically determined after loss on ignition [30]. The sediment samples were first dried at $60^{\circ} \mathrm{C}$ for $6 \mathrm{~h}$ and weighed on a Scaltec SBC21 microbalance (accuracy $0.1 \mathrm{mg}$ ) to obtain the dry weight. Samples were then combusted in a muffle furnace $\left(550^{\circ} \mathrm{C}\right.$ for $4 \mathrm{~h}$ ) and reweighed to determine the ash fraction. The organic fraction content was calculated by subtracting the ash weight from the total weight.

2.4. Nematode Study. Nematode specimens were extracted by decantation or by centrifugation through a silica gel gradient (Ludox HS 30, density $1.18 \mathrm{~g} \mathrm{~cm}^{-3}$ ) [31]. About 100 nematode specimens from each sample were picked out under a stereomicroscope, transferred into glycerine, and mounted on permanent slides. Nematode species identification was performed using a light microscope equipped with Nomarski optics (Optiphot-2 Nikon) and aided by the pictorial keys in Platt and Warwick [32,33], Warwick et al. [34], and other relevant literature available on Deprez et al. [35]. Genera and species identified in this study are reported in alphabetical order (Table 1). The validity of scientific names was verified based on Deprez et al. [35] and WoRMS (http://www.marinespecies.org/). Synonymies species were also consulted in Gerlach and Riemann [36]. The habitat features (i.e., depth and sediment type) of the described taxa are indicated by symbols.

Current data on the distribution of Italian marine fauna as well as nematodes species [9] cover the nine biogeographical zones of the Italian sea as suggested by Bianchi [37]. In this sense, the area sampled in the present study is also part of the North Adriatic sector.

\section{Results}

The granulometric analysis of the sediment samples revealed that all the shallow subtidal sites $(1.5-3 \mathrm{~m}$ in depth) are characterized as medium-fine sand $(\mathrm{Mz} 250 \mu \mathrm{m})$. These samples contained a high percentage of sand (96\%) very low contents of mud (3\%) and gravel (1\%). On the other 
TABLE 1: List of nematode species found along the Marches coast and their distribution in the Mediterranean and Adriatic Seas. Sampling site and habitat/sediment type are reported for each species.

\begin{tabular}{|c|c|c|c|c|}
\hline Species & Sampling site & Habitat/sediment & New records ${ }^{1,2,3}$ & $\begin{array}{l}\text { Distribution in the } \\
\text { Mediterranean Sea }\end{array}$ \\
\hline \multicolumn{5}{|l|}{ Order Enoplida } \\
\hline \multicolumn{5}{|l|}{ Family Anoplostomatidae } \\
\hline Chaetonema riemanni Platt 1973 & $\mathrm{BR}$ & SSL/MS & - $(\mathrm{A}$ and $\mathrm{M})$ & - \\
\hline \multicolumn{5}{|l|}{ Family Anticomidae } \\
\hline Anticoma eberthi Bastian 1865 & FI & SSL/MS & & North Adriatic Sea \\
\hline \multicolumn{5}{|l|}{ Family Enchelidiidae } \\
\hline Eurystomina ornata (Eberth 1863) & $\mathrm{BR}$ & SSL/MS & & $\begin{array}{l}\text { North Adriatic, Ligurian } \\
\text { and South Tyrrhenian Sea }\end{array}$ \\
\hline \multicolumn{5}{|l|}{ Family Oncholaimidae } \\
\hline Metoncholaimus albidus (Bastian 1865) & FI, BR, P & SSL/MS & $\bullet(\mathrm{A})$ & South Tyrrhenian Sea \\
\hline Oncholaimellus calvadosicus De Man 1890 & FI, BR & SSL/MS & - $(\mathrm{A}$ and $\mathrm{M})$ & - \\
\hline $\begin{array}{l}\text { Oncholaimus campylocercoides De Coninck \& } \\
\text { Schuurmans Stekhoven } 1933\end{array}$ & FI, BR, P & $\mathrm{SSL} / \mathrm{MS}$ & & $\begin{array}{l}\text { North and South Adriatic } \\
\text { Sea, Ligurian and South } \\
\text { Tyrrhenian Sea }\end{array}$ \\
\hline Oncholaimus dujardinii de Man 1876 & FI, BR & $\mathrm{FO}, \mathrm{SSL} / \mathrm{MS}$ & & $\begin{array}{l}\text { North Adriatic, Ligurian } \\
\text { and South Tyrrhenian Sea }\end{array}$ \\
\hline Oncholaimus oxyuris Ditlevsen 1911 & FI, BR, P & FO, SSL/MS & - $(\mathrm{A}$ and $\mathrm{M})$ & - \\
\hline Viscosia abyssorum (Allgén 1933) & BR & SSL/MS & & North Adriatic Sea \\
\hline Viscosia elegans (Kreis 1924) & FI, BR, P & SSL/MS & $\bullet(\mathrm{A})$ & French Coast \\
\hline \multicolumn{5}{|l|}{ Family Oxystominidae } \\
\hline Thalassoalaimus tardus de Man 1893 & FI & $\mathrm{SL} / \mathrm{MU}$ & - $(\mathrm{A}$ and $\mathrm{M})$ & - \\
\hline \multicolumn{5}{|l|}{ Family Thoracostomopsidae } \\
\hline Mesacanthion diplechma (Southern 1914) & FI, BR & SSL/MS & & North Adriatic Sea \\
\hline \multicolumn{5}{|l|}{ Family Tripyloididae } \\
\hline Bathylaimus tenuicaudatus (Allgén 1933) & FI, BR & SSL/MS & - $(\mathrm{A}$ and $\mathrm{M})$ & - \\
\hline \multicolumn{5}{|l|}{ Order Trefusiida } \\
\hline \multicolumn{5}{|l|}{ Family Trefusiidae } \\
\hline Trefusia filicauda Allgén 1933 & $\mathrm{BR}$ & SSL/MS & & $\begin{array}{l}\text { North Adriatic Sea and } \\
\text { French Coast }\end{array}$ \\
\hline \multicolumn{5}{|l|}{ Order Chromadorida } \\
\hline \multicolumn{5}{|l|}{ Family Chromadoridae } \\
\hline Chromadorella duopapillata Platt 1973 & FI, BR & SSL/MS & & North Adriatic Sea \\
\hline Hypodontolaimus cf. dimorphus Wieser 1954 & FI, BR & SSL/MS & - $(\mathrm{A}$ and $\mathrm{M})$ & - \\
\hline Prochromadorella ditlevseni (de Man 1922) & FI, BR & $\mathrm{SSL} / \mathrm{MS}$ & & North Adriatic Sea \\
\hline Prochromadorella septempapillata Platt 1973 & FI, BR, P & SSL/MS & & North Adriatic Sea \\
\hline Ptycholaimellus pandispiculatus (Hopper 1961) & FI, BR & SSL/MS & - (A and $M)$ & - \\
\hline \multicolumn{5}{|l|}{ Family Cyatholaimidae } \\
\hline Cyatholaimus gracilis (Eberth 1863) & FI, BR & SSL/MS & & $\begin{array}{l}\text { North Adriatic, Ligurian } \\
\text { and South Tyrrhenian Sea, } \\
\text { and French coast }\end{array}$ \\
\hline Pomponema sedecima Platt 1973 & FI, BR & SSL/MS & - $(\mathrm{A}$ and $\mathrm{M})$ & - \\
\hline Praeacanthonchus opheliae (Warwick 1970) & $\mathrm{BR}$ & SSL/MS & - $(\mathrm{A}$ and $\mathrm{M})$ & - \\
\hline \multicolumn{5}{|l|}{ Family Desmodoridae } \\
\hline Chromaspirina inglisi Warwick 1970 & FI & SSL/MS & - $(\mathrm{A}$ and $\mathrm{M})$ & - \\
\hline
\end{tabular}


TABle 1: Continued.

\begin{tabular}{|c|c|c|c|c|}
\hline Species & Sampling site & Habitat/sediment & New records ${ }^{1,2,3}$ & $\begin{array}{l}\text { Distribution in the } \\
\text { Mediterranean Sea }\end{array}$ \\
\hline \multicolumn{5}{|l|}{ Family Neotonchidae } \\
\hline Filitonchus filiformis (Warwick 1971) & FI & $\mathrm{SSL} / \mathrm{MS}$ & - $(\mathrm{A}$ and $\mathrm{M})$ & - \\
\hline \multicolumn{5}{|l|}{ Family Leptolaimidae } \\
\hline Stephanolaimus jayasreei Platt 1983 & FI & SSL/MS & - $(\mathrm{A}$ and $\mathrm{M})$ & - \\
\hline \multicolumn{5}{|l|}{ Family Microlaimidae } \\
\hline Microlaimus teutonicus Riemann 1966 & FI & SSL/MS & - $(\mathrm{A}$ and $\mathrm{M})$ & - \\
\hline \multicolumn{5}{|l|}{ Family Monoposthiidae } \\
\hline Monoposthia mirabilis Schulz 1932 & FI & SSL/MS & & $\begin{array}{l}\text { North Adriatic and South } \\
\text { Tyrrhenian Sea }\end{array}$ \\
\hline Monoposthia costata (Bastian 1865) & $\mathrm{BR}, \mathrm{FI}$ & SSL/MS & & $\begin{array}{l}\text { North Adriatic, Ligurian } \\
\text { and Tyrrhenian Sea }\end{array}$ \\
\hline \multicolumn{5}{|l|}{ Family Selachinematidae } \\
\hline Halichoanolaimus dolichurus Ssaweljev 1912 & FI & $\mathrm{SL} / \mathrm{MU}$ & & $\begin{array}{l}\text { North Adriatic and South } \\
\text { Tyrrhenian Sea, French } \\
\text { coast }\end{array}$ \\
\hline Synonchiella riemanni Warwick 1970 & FI & SSL/MS & - $(\mathrm{A}$ and $\mathrm{M})$ & - \\
\hline \multicolumn{5}{|l|}{ Order Monhysterida } \\
\hline \multicolumn{5}{|l|}{ Family Axonolaimidae } \\
\hline Ascolaimus elongatus (Bütschli 1874) & FI & SL/MU & $\bullet(\mathrm{A})$ & $\begin{array}{l}\text { Ligurian and South } \\
\text { Tyrrhenian Sea }\end{array}$ \\
\hline Odontophora rectangula Lorenzen 1972 & FI, BR, P & SSL, SL/MS, MU & & North Adriatic Sea \\
\hline Odontophora wieseri Luc \& De Coninck 1959 & FI & SSL/MS & - $(\mathrm{A}$ and $\mathrm{M})$ & - \\
\hline \multicolumn{5}{|l|}{ Family Comesomatidae } \\
\hline $\begin{array}{l}\text { Dorylaimopsis mediterranea Grimaldi-De Zio } \\
1968\end{array}$ & FI & $\mathrm{SL} / \mathrm{MU}$ & & $\begin{array}{l}\text { North and South Adriatic } \\
\text { Sea and French coast }\end{array}$ \\
\hline Sabatieria breviseta Stekhoven 1935 & FI, BR & SL/MU & & North Adriatic Sea \\
\hline Sabatieria ornata (Ditlevsen 1918) & FI, BR & SSL, SL/MS, MU & & North Adriatic Sea \\
\hline Sabatieria pulchra (Schneider 1906) & BR, FI, P & SSL, SL/MS, MU & & $\begin{array}{l}\text { North Adriatic Sea and } \\
\text { French Coast }\end{array}$ \\
\hline Setosabatieria fibulata (Wieser 1949) & FI & SSL, SL/MS, MU & - $(\mathrm{A}$ and $\mathrm{M})$ & - \\
\hline Setosabatieria hilarula (de Man 1922) & FI & SSL, SL/MS, MU & & $\begin{array}{l}\text { North and South Adriatic } \\
\text { and Ligurian Sea }\end{array}$ \\
\hline \multicolumn{5}{|l|}{ Family Linhomoeidae } \\
\hline Metalinhomoeus longiseta Kreis 1929 & FI & SSL/MS & - $(\mathrm{A}$ and $\mathrm{M})$ & - \\
\hline Terschellingia longicaudata de Man 1907 & FI & SL/MU & & $\begin{array}{l}\text { North Adriatic Sea and } \\
\text { French Coast }\end{array}$ \\
\hline \multicolumn{5}{|l|}{ Family Xyalidae } \\
\hline Cobbia caledonia Warwick \& Platt 1973 & FI & SSL/MS & - $(\mathrm{A}$ and $\mathrm{M})$ & - \\
\hline Cobbia trefusiaeformis de Man 1907 & FI & SSL/MS & - $(\mathrm{A}$ and $\mathrm{M})$ & - \\
\hline Daptonema curvatus Gerlach 1956 & FI, BR & SSL/MS & - $(\mathrm{A}$ and $\mathrm{M})$ & - \\
\hline Daptonema fistulatum (Wieser \& Hopper 1967) & FI, BR & SSL/MS & - $(\mathrm{A}$ and $\mathrm{M})$ & - \\
\hline Daptonema furcatum (Juario 1974) & FI, BR & SSL/MS & & North Adriatic Sea \\
\hline $\begin{array}{l}\text { Paramonhystera buetschlii(Bresslau \& Stekhoven } \\
\text { in Stekhoven 1935) }\end{array}$ & FI, BR & SSL/MS & - $(\mathrm{A})$ & Mediterranean Sea \\
\hline Theristus acer Bastian 1865 & FI, BR & SSL/MS & & $\begin{array}{l}\text { Spanish coast, North } \\
\text { Adriatic, and South } \\
\text { Tyrrhenian Sea }\end{array}$ \\
\hline
\end{tabular}


TABLE 1: Continued.

\begin{tabular}{|c|c|c|c|c|}
\hline Species & Sampling site & Habitat/sediment & New records ${ }^{1,2,3}$ & $\begin{array}{l}\text { Distribution in the } \\
\text { Mediterranean Sea }\end{array}$ \\
\hline Theristus denticulatus Warwick 1970 & FI & SSL/MS & - $(\mathrm{A}$ and $\mathrm{M})$ & - \\
\hline Theristus flevensis Stekhoven 1935 & FI & SSL/MS & & North Adriatic Sea \\
\hline Trichotheristus floridanus (Wieser \& Hopper 1967) & FI, BR & SSL/MS & - $(\mathrm{A}$ and $\mathrm{M})$ & - \\
\hline $\begin{array}{l}\text { Trichotheristus mirabilis (Stekhoven \& De } \\
\text { Coninck 1933) }\end{array}$ & FI & SSL/MS & & $\begin{array}{l}\text { North Adriatic, Ligurian } \\
\text { and South Tyrrhenian Sea }\end{array}$ \\
\hline
\end{tabular}

[•: new record in the Adriatic Sea (A) and in the Mediterranean Sea (M); FO: foreshore; MS: medium sands; MU: muddy sediments; SL: sublittoral; SSL: shallow sublittoral].

Note: ${ }^{1}$ Travizi and Vidaković [13]; ${ }^{2}$ Semprucci et al. [9]; ${ }^{3}$ http://www.marinespecies.org.

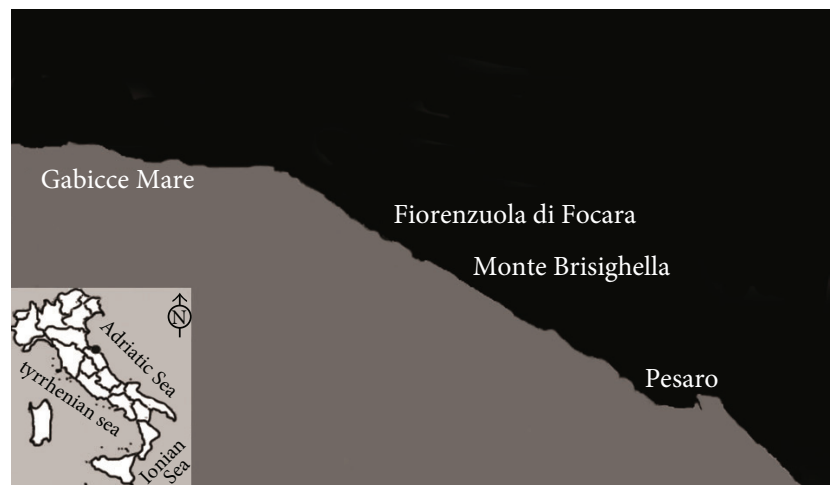

FIGURE 1: Study area and study sites.

hand, the sediments of the subtidal site ( $12 \mathrm{~m}$ in depth) were characterized as muddy sediments ( $\mathrm{Mz} 25 \mu \mathrm{m})$ with a higher mud content (64\%), followed by sand (35\%) and gravel (1\%). The total organic content (TOM) was lower in the shallow subtidal sites (2\%) than that in the deeper sites (5\%).

Overall, 84 putative species of nematodes were recognized. These belonged to 52 genera and 22 families, 51 of which have been identified to species level (Table 1). The highest number of species belonged to the families Xyalidae (16), Chromadoridae (10), Axonolaimidae (7), Comesomatidae (7), Cyatholaimidae (7), and Oncholaimidae (7). The highest number of species was recorded at the shallow subtidal sites. The most common families were the Anticomidae, Axonolaimidae, Chromadoridae, Comesomatidae, Cyatholaimidae, Oncholaimidae, and Xyalidae, while Anoplostomatidae, Ceramonematidae, Enchelidiidae, Leptolaimidae, Neotonchidae, Oxystominidae, Sphaerolaimidae, and Trefusiidae were very rare.

The Xyalidae family, one of the most specious families, had 16 putative species (11 identified to species level) distributed into 6 genera: Cobbia, Daptonema, Gonionchus, Paramonhystera, Theristus, and Trichotheristus. Most species were identified in the genera Daptonema (3 species and 2 putative species) and Theristus (3 species) (Table 1). Chromadoridae showed 11 putative species (6 identified to species) in 7 genera: Chromadora, Chromadorella, Dichromadora, Hypodontolaimus, Neochromadora, Prochromadorella and Ptycholaimellus. Dichromadora and Prochromadorella presented the higher number of putative species (Dichromadora with 2 putative species, and Prochromadorella with 2 species $P$. ditlevseni and P. septempapillata).
Comesomatidae were represented by 7 putative species in 4 genera (Dorylaimopsis, Paramesonchium, Sabatieria, and Setosabatieria). Axonolaimidae presented 7 putative species in 4 genera: Ascolaimus, Axonolaimus, Odontophora, and Parodontophora. Odontophora was the more frequent and specious genus with 2 species (O. rectangula and O. wieseri) and two putative species.

Cyatholaimidae were represented by 7 putative species (3 only identified to species) which belong to the following genera: Cyatholaimus, Pomponema, and Praeacanthonchus.

Oncholaimidae were represented by 4 genera: Metoncholaimus, Oncholaimellus, Oncholaimus, Viscosia. Oncholaimus was the richer genus, with 3 species (O. campylocercoides, $O$. dujardinii, and O. oxyuris), followed by Viscosia (V. elegans and V. abyssorum).

A comparison with the data on species distribution from Gerlach and Riemann [36], Deprez et al. [35], WoRMS [38], and Travizi and Vidaković [13] revealed that 27 of the 51 species found in the present study were new for the Adriatic nematofauna: Chaetonema riemanni Platt, 1973; Metoncholaimus albidus (Bastian 1865); Oncholaimellus calvadosicus De Man, 1890; Oncholaimus oxyuris Ditlevsen 1911; Viscosia elegans (Kreis 1924); Thalassoalaimus tardus De Man 1893; Bathylaimus tenuicaudatus (Allgén 1933); Hypodontolaimus cf. dimorphus Wieser 1954, Ptycholaimellus pandispiculatus (Hopper 1961), Setosabatieria fibulata (Wieser 1949); Pomponema sedecima Platt 1973; Praeacanthonchus opheliae (Warwick 1970); Chromaspirina inglisi Warwick 1970; Filitonchus filiformis (Warwick 1971); Stephanolaimus jayasreei Platt 1983; Microlaimus teutonicus Riemann 1966; Synonchiella riemanni Warwick 1970; Ascolaimus elongatus 
(Bütschli 1874); Odontophora wieseri Luc \& De Coninck 1959; Metalinhomoeus longiseta Kreis 1929; Cobbia caledonia Warwick \& Platt 1973; Cobbia trefusiaeformis de Man 1907; Daptonema curvatus Gerlach 1956; Daptonema fistulatum (Wieser \& Hopper 1967); Paramonhystera buetschlii (Bresslau \& Stekhoven in Stekhoven 1935); Trichotheristus floridanus (Wieser \& Hopper 1967). Only four of these species were already known in Mediterranean Sea: Metoncholaimus albidus (Bastian 1865) recorded in the South Tyrrhenian Sea, Viscosia elegans (Kreis 1924) present in the French Coasts, Ascolaimus elongatus (Bütschli 1874) in the Ligurian and South Tyrrhenian Sea, and Paramonhystera buetschlii (Bresslau \& Stekhoven in Stekhoven 1935) in the Mediterranean Sea. The species identified during this survey have been only been recorded in the northern Atlantic and/or North Sea (Table 1) and in some cases also in the Black Sea, Canary Islands, and Antarctic Ocean [35, 36, 38].

\section{Discussion}

The general composition of the nematode fauna found in this study seems related to the habitat and sediment types (i.e., medium-fine sands) [13]. Most of the recorded species are in the shallow sublittoral zones: this may be related both to a more extensive investigation carried out in the shallow waters and/or to a lower nematode richness and diversity found offshore [26]. Indeed, the increase in the biodiversity of nematodes in parallel with the size of the sediment is well known $[4,39,40]$. In fact, the sediment grain size appears to be one of the main environmental variables influencing the horizontal distribution of nematodes. Different sediment types are characterized by different nematode assemblages and by a predominance of specific families, so-called isocommunities or parallel communities (see [4, 41, 42]).

Although Xyalidae is a family usually predominant in fine sediments, it may occur (with different ratio) in a wide range of sediment types, from muddy to coarse sands [4, 26, 40, 43]. All the Xyalidae specimens identified at specific level were found in shallow sites and are typical of intertidal habitats (see [34]) (Table 1). The highest diversity of this family in the shallow waters proves the importance of genera like Theristus and Daptonema in this environment, which includes sheltered habitats with medium-to-fine sands. On the other hand, Comesomatidae representatives are commonly related to muddy sediments, often characterized by anoxic conditions $[4,26,44]$. Indeed, these species were more diverse and abundant in the offshore station of FI, characterized by sediments with a high content of mud and organic matter. In muddy sediments, this family can be dominant, representing up to $34 \%$ of the total nematode community [26]. Comesomatidae were mostly represented by species of the genus Sabatieria: S. breviseta, S. pulchra, S. ornata, as well as by Dorylaimopsis mediterranea, S. fibulata, and S. hilarula. Among these species, S. pulchra is known to be physiologically well-adapted to stress conditions (see [39]), being able to survive in de-oxygenated sediments as a facultative anaerobic species [45]. However, S. ornata seems to be confined to the oxidized sediment layers. Among the species found offshore, Terschellingia longicaudata, T. tardus, Halichoanolaimus dolichurus, O. rectangula, and A. elongatus are typical of fine sediments rich in silt fraction [34, 46-48]. However, some of the offshore species were also found in the coastal stations (e.g., O. rectangula, S. breviseta, S. pulchra, S. ornata, and S. fibulata). The specious Oncholaimidae was one of the most widespread and abundant nematode family in the shallow waters, with some species typical of intertidal zone and coarse sands $[4,34]$, while being less representative offshore [26]. This might be related to the life strategy of some species within this family, which might be sensible to anoxic conditions found offshore [49]. Species, such as O. campylocercoides, might be an exception. Frequently in anoxic sediments, O. campylocercoides and T. longicaudata present sub-epidermic grains that probably represent a detoxification mechanism from the high sulfide concentrations $[50,51]$. As Comesomatidae, Linhomoeidae and Xyalidae are dominant and characteristic of muddy sediments, whereas the importance of Chromadoridae increases with the increasing of median grain size $[4,40,48]$. In fact, Chromadoridae were more frequent and abundant in the shallow sublittoral samples, with species typical of the intertidal zone and sandy substrates.

Biogeographic hypotheses for most of the inconspicuous meiofaunal organisms, and thus also for nematodes, are often very difficult. This is mainly due to the "taxonomic crisis" that concerns most meiofaunal taxa and also noticeable by the significant decrease of biodiversity surveys in the last decades $[8,52]$. Costello et al. [53], updating the European marine biodiversity inventory, have highlighted that the majority of the nematode reports in the Mediterranean area comes from out of date literature as well as total absence of identification guides for the Mediterranean basin. Furthermore, the guides often only report the widespread, common, and/or ecologically significant species. In contrast, many of the rarer or taxonomically ambiguous species (often because of the very poor quality of the original descriptions) are not covered in any guides. A consequence is that the first species are much more frequently reported in the faunistic studies and thus present wider distribution, while the latter species appear to be locally distributed.

Overall, the families and genera reported in this study show a wide global distribution, while the species detected are typical of the North Western Europe or the Northern Atlantic; see Deprez et al. [35] and WoRMS [38]. This is in part due to the presence of most marine nematode taxonomists in the North Western Europe. In addition, most of the marine nematode literature is concentrated in this region. All these elements must be considered when inferences on nematode distribution and biogeography are discussed. Furthermore, recently Fontaneto and Hortal [54] have recently brought up the question "if microorganisms-freshwater animals lower than $2 \mathrm{~mm}$ - can have a biogeography" to the attention of the scientific community. The authors argue about the "Everything is Everywhere" (EisE) hypothesis, suggesting that the geographical distribution of these organisms may be strongly influenced by their animal size. Indeed, for inconspicuous freshwater organisms, the high potential for dispersal might contribute more in determining a wider distribution than 
that in the large ones [55]. The occurrence of morphologically identical nematode species in completely divergent habitats ("meiofauna paradox" sensu Giere, [56]) is also common in marine meiofauna. However, the existence of cryptic species (a complex of morphologically identical species which can only be differentiated by DNA) or a parallel evolution in response to similar microhabitats seems to be more plausible explanation to this trend than the dispersal capacities (see for review [41]). Therefore, theories on the biogeography of nematodes as well as other meiofaunal groups should be proposed with caution.

The present study represents a first attempt to increase the knowledge of free-living marine nematodes in the Adriatic basin and the Mediterranean Sea. It aims to establish the basis for a future discussion of the biogeography of marine nematodes in the Mediterranean Sea, currently biased by also dated and fragmentary information.

\section{Conclusions}

Biodiversity investigations aim to integrate species checklists and the compilation of databases that represent a regional and global benefit for researchers worldwide. Furthermore, the monitoring of biodiversity over time is of great importance for planning conservation actions, which seems to be more urgent these days, especially in vulnerable coastal systems. This study represents the first survey of the marine nematodes in the Marches coasts. The families with the highest abundance and diversity found in this study are typical of intertidal habitats, especially in sediments characterized by mediumfine sands. Most nematode species found in this study were previously reported only in the North Western Europe and the North Atlantic which are the most known regions regarding marine nematodes. This shows the necessity of intensifying sampling efforts in other regions to improve the current knowledge of marine nematode distribution as well as to clarify their biogeographic patterns.

\section{Acknowledgments}

The author warmly thanks the anonymous reviewers for their helpful comments that were material in improving the paper. A special thank is due to Professor Susanna Grimaldi-De Zio for her encouragement and precious theoretical and practical help in the study of marine nematodes.

\section{References}

[1] H. M. Platt and R. M. Warwick, "Chapter 10, The significance of free-living nematodes to the littoral ecosystem," in The Shore Environment-2. Ecosystems, J. H. Price and D. E. G. Irvine, Eds., pp. 729-759, London, UK, 1980.

[2] P. J. D. Lambshead, in Nematology: Advances and Perspectives - Vol 1: Nematode Morphology, Physiology and Ecology, Z. X. Chen, S. Y. Chen, and D. W. Dickson, Eds., Marine Nematode Biodiversity, pp. 436-467, CABI Publishing, Wallingford, UK, 2004.
[3] I. Andrássy, "A short census of free-living nematodes," Fundamental and Applied Nematologie, vol. 15, pp. 187-188, 1992.

[4] C. Heip, M. Vincx, and G. Vranken, "The ecology of marine nematodes," Oceanography and Marine Biology an Annual Review, vol. 23, pp. 399-489, 1985.

[5] O. Giere, Meiobenthology: The Microscopic Motile Fauna of Aquatic Sediments, Springer, Berlin, Germany, 2nd edition, 2009.

[6] M. Moreno, F. Semprucci, L. Vezzulli, M. Balsamo, M. Fabiano, and G. Albertelli, "The use of nematodes in assessing ecological quality status in the Mediterranean coastal ecosystems," Ecological Indicators, vol. 11, no. 2, pp. 328-336, 2011.

[7] E. Abebe, W. Decraemer, and P. De Ley, "Global diversity of nematodes (Nematoda) in freshwater," Hydrobiologia, vol. 595, no. 1, pp. 67-78, 2008.

[8] M. Balsamo, G. Albertelli, V. U. Ceccherelli et al., "Meiofauna of the adriatic sea: present knowledge and future perspectives," Chemistry and Ecology, vol. 26, no. 1, pp. 45-63, 2010.

[9] F. Semprucci, R. Sandulli, and S. De Zio-Grimaldi, "Adenophorea, nematodi marini," in Checklist della Flora e della Fauna dei Mari Italiani, G. Relini, Ed., vol. 15 of Biologia Marina Mediterranea, pp. 184-209, 2008.

[10] C. Allgén, "Die freilebenden Nematoden des Mittelmeeres," Zoologische Jahrbücher, vol. 76, pp. 1-102, 1942.

[11] J. H. Schuurmans-Stekhoven, "The free-living marine nemas of the Mediterranean-I. The Bay of Villefranche," Institut Royal Des Sciences Naturelles De Belgique Memoires, vol. 37, pp. 1-220, 1950.

[12] S. A. Gerlach, "Die Nematodenbesiedlung des Sandstrandes und des Küstengrundwassers an der italienischen Küste-I. Systematischer Teil," Archivio Zoologico Italiano, vol. 37, pp. 517-640, 1953.

[13] A. Travizi and J. Vidaković, "Nematofauna in the Adriatic Sea: review and check-list of free-living nematode species," Helgolander Meeresuntersuchungen, vol. 51, no. 4, pp. 503-519, 1997.

[14] V. U. Ceccherelli and F. Cevidalli, "Osservazioni preliminari sulla bionomia dei popolamenti meiobentonici della Sacca di Scardovari (Delta del Po), con particolare riferimento ai Nematodi ed ai Copepodi," Quaderni del laboratorio di Tecnologia della Pesca. Atti del Congresso S.I.B.M., 1981.

[15] A. Guerrini, M. A. Colangelo, and V. U. Ceccherelli, "Recolonization patterns of meiobenthic communities in brackish vegetated and unvegetated habitats after induced hypoxia/anoxia," Hydrobiologia, vol. 375-376, pp. 73-87, 1998.

[16] S. De Zio, "Distribuzione dei nematodi in spiagge pugliesi," Bollettino Di Zoologia, vol. 31, no. 2, pp. 907-920, 1964.

[17] S. De Zio, "Nematodi marini del litorale pugliese," Bollettino di Zoologia, vol. 33, p. 182, 1966.

[18] S. Grimaldi-De Zio, "Il popolamento di Nematodi di una spiaggia pugliese in rapporto al ritmo di marea," Bollettino di Zoologia, vol. 34, p. 126, 1967.

[19] S. Grimaldi-De Zio, "Una nuova specie di nematodi Comesomatidae: dorylaimopsis mediterraneus," Bollettino di Zoologia, vol. 35, pp. 137-141, 1968.

[20] S. Grimaldi-De Zio, "Confronto fra Nematodi del fango coralligeno di piattaforma e una comunità del fango dello stesso distretto adriatico," Bollettino di Zoologia, vol. 35, p. 347, 1968.

[21] R. Sandulli, S. De Zio-Grimaldi, M. Gallo D’Addabbo, L. Caló, and E. Bressan, "Aspetti della biodiversità della meiofauna lungo il litorale pugliese," Biologia Marina Mediterranea, vol. 9, no. 1, pp. 484-493, 2001. 
[22] R. Sandulli, C. de Leonardis, and J. Vanaverbeke, "Meiobenthic communities in the shallow subtidal of three Italian Marine Protected Areas," Italian Journal of Zoology, vol. 77, no. 2, pp. 186-196, 2010.

[23] J. Vidaković, A. Travizi, and G. Boucher, "Two new species of the genus Metacyatholaimus (Nematoda, Cyatholaimidae) from the Adriatic Sea with a key to the species," Cahiers de Biologie Marine, vol. 44, no. 2, pp. 111-120, 2003.

[24] C. de Leonardis, R. Sandulli, J. Vanaverbeke, M. Vincx, and S. De Zio, "Meiofauna and nematode diversity in some Mediterranean subtidal areas of the Adriatic and Ionian Sea," Scientia Marina, vol. 72, no. 1, pp. 5-13, 2008.

[25] A. Travizi, "The nematode fauna of the northern Adriatic offshore sediments: community structure and biodiversity," Acta Adriatica, vol. 51, no. 2, pp. 169-180, 2010.

[26] F. Semprucci, P. Boi, A. Manti et al., "Benthic communities along a littoral of the Central Adriatic Sea (Italy)," Helgoland Marine Research, vol. 64, no. 2, pp. 101-115, 2010.

[27] P. Franco, L. Jeftic, P. Malanotte-Rizzoli, A. Michelato, and M. Orlic, "Descriptive model of the northern Adriatic," Oceanologica Acta, vol. 5, pp. 379-389, 1982.

[28] M. Zavatarelli, J. W. Baretta, J. G. Baretta-Bekker, and N. Pinardi, "The dynamics of the Adriatic Sea ecosystem. An idealized model study," Deep-Sea Research Part I, vol. 47, no. 5, pp. 937-970, 2000.

[29] J. B. Buchanan, "Sediment analysis," in Methods for the Study of Marine Benthos, N. A. Holme and A. D. McIntyre, Eds., pp. 41-65, Blackwell Scientific Publications, Oxford, UK, 1984.

[30] J. B. Buchanan, "Measurement of the physical and chemical environment," in Methods for the Study of Marine Benthos, N. A. Holme and A. D. McIntyre, Eds., pp. 30-52, Blackwell Scientific Publications, Oxford, UK, 1971.

[31] O. Pfannkuche and H. Thiel, "Sample processing," in Introduction to the Study of Meiofauna, R. P. Higgins and H. Thiel, Eds., pp. 134-145, Smithsonian Institute, Washington, DC, USA, 1988.

[32] H. M. Platt and R. M. Warwick, "Free-living marine nematodes-part I. British Enoplids," in Synopses of the British Fauna, vol. 28, Cambridge University Press, Cambridge, UK, 1983.

[33] H. M. Platt and R. M. Warwick, "Free-living marine nematodes-part II. British Chromadorids," in Synopses of the British Fauna, vol. 38, Brill, Leiden, Holland, 1988.

[34] R. M. Warwick, H. M. Platt, and P. J. Somerfield, "Free-living marine nematodes-part III. British monhysterids," in Synopses of the British Fauna, vol. 53, Field Studies Council, Shrewsbury, UK, 1998.

[35] T. Deprez, E. Vanden Berghe, and M. Vincx, World Wide Web electronic publication, 2005, http://www.nemys.ugent.be.

[36] S. A. Gerlach and F. Riemann, The Bremerhaven Checklist of Aquatic Nematodes. A catalogue of Nematoda Adenophorea excluding the Dorylaimida. Veröffentlichungen des Instituts für Meeresforschung in Bremerhaven, 4 Part I and Part II,19731974.

[37] C. N. Bianchi, "Proposta di suddivisione dei mari italiani in settori biogeografici," Notiziario SIBM, vol. 46, pp. 57-59, 2004.

[38] World Register of Marine Species (WoRMS), 2009, http:// www.marinespecies.org.

[39] M. Steyaert, N. Garner, D. Van Gansbeke, and M. Vincx, "Nematode communities from the North Sea: environmental controls on species diversity and vertical distribution within the sediment," Journal of the Marine Biological Association of the United Kingdom, vol. 79, no. 2, pp. 253-264, 1999.

[40] F. Semprucci, P. Colantoni, G. Baldelli, M. Rocchi, and M. Balsamo, "The distribution of meiofauna on back-reef sandy platforms in the Maldives (Indian Ocean)," Marine Ecology, vol. 31, no. 4, pp. 592-607, 2010.

[41] M. Raes, W. Decraemer, and A. Vanreusel, "Walking with worms: coral-associated epifaunal nematodes," Journal of Biogeography, vol. 35, no. 12, pp. 2207-2222, 2008.

[42] T. Gheskiere, M. Vincx, B. Urban-Malinga, C. Rossano, F. Scapini, and S. Degraer, "Nematodes from wave-dominated sandy beaches: diversity, zonation patterns and testing of the isocommunities concept," Estuarine, Coastal and Shelf Science, vol. 62, no. 1-2, pp. 365-375, 2005.

[43] F. Semprucci, P. Colantoni, C. Sbrocca, G. Baldelli, M. Rocchi, and M. Balsamo, "Meiofauna in sandy back-reef platforms differently exposed to the monsoons in the Maldives (Indian Ocean)," Journal of Marine Systems, vol. 87, no. 3-4, pp. 208-215, 2011.

[44] M. Moreno, G. Albertelli, and M. Fabiano, "Nematode response to metal, PAHs and organic enrichment in tourist marinas of the mediterranean sea," Marine Pollution Bulletin, vol. 58, no. 8, pp. 1192-1201, 2009.

[45] P. Jensen, "Ecology of benthic and epiphytic nematodes in brackish waters," Hydrobiologia, vol. 108, no. 3, pp. 201-217, 1984.

[46] C. Heip, R. Huys, M. Vincx et al., "Composition, distribution, biomass and production of North Sea meiofauna," Netherlands Journal of Sea Research, vol. 26, no. 2-4, pp. 333-342, 1990.

[47] A. Vanreusel, "Ecology of free-living marine nematodes in the Voordelta (Southern Bight of the North Sea)-II. Habitat preferences of the dominant species," Nematologica, vol. 37, no. 3, pp. 343-359, 1991.

[48] M. Schratzberger, K. Warr, and S. I. Rogers, "Patterns of nematode populations in the southwestern North Sea and their link to other components of the benthic fauna," Journal of Sea Research, vol. 55, no. 2, pp. 113-127, 2006.

[49] T. Bongers, R. Alkemade, and G. W. Yeates, "Interpretation of disturbance-induced maturity decrease in marine nematode assemblages by means of the Maturity Index," Marine Ecology Progress Series, vol. 76, no. 2, pp. 135-142, 1991.

[50] L. J. Jacobs and J. Heyns, "Notes brèves. An ecological strategy in the genus Monhystera-an hypothesis," Revue de Nématologie, vol. 13, pp. 109-111, 1990.

[51] F. Thiermann, B. Vismann, and O. Giere, "Sulphide tolerance of the marine nematode Oncholaimus campylocercoides-a result of internal sulphur formation?" Marine Ecology Progress Series, vol. 193, pp. 251-259, 2000.

[52] M. Curini-Galletti, "Platyhelminthes. La checklist della fauna marina Italiana," in Checklist della Flora e della Fauna dei Mari Italiani, G. Relini, Ed., vol. 15 of Biologia Marina Mediterranea, pp. 110-124, 2008.

[53] M. J. Costello, P. Bouchet, C. S. Emblow, and A. Legakis, "European marine biodiversity inventory and taxonomic resources: state of the art and gaps in knowledge," Marine Ecology Progress Series, vol. 316, pp. 257-268, 2006.

[54] D. Fontaneto and J. Hortal, "Do microorganisms have biogeography?" The International Biogeography Society, vol. 6, no. 1, pp. 3-7, 2008. 
[55] C. A. Kellogg and D. W. Griffin, "Aerobiology and the global transport of desert dust," Trends in Ecology and Evolution, vol. 21, no. 11, pp. 638-644, 2006.

[56] O. Giere edition, Meiobenthology, The Microscopic Motile Fauna of Aquatic Sediments, Springer, Berlin, Germany, 1st edition, 1993. 

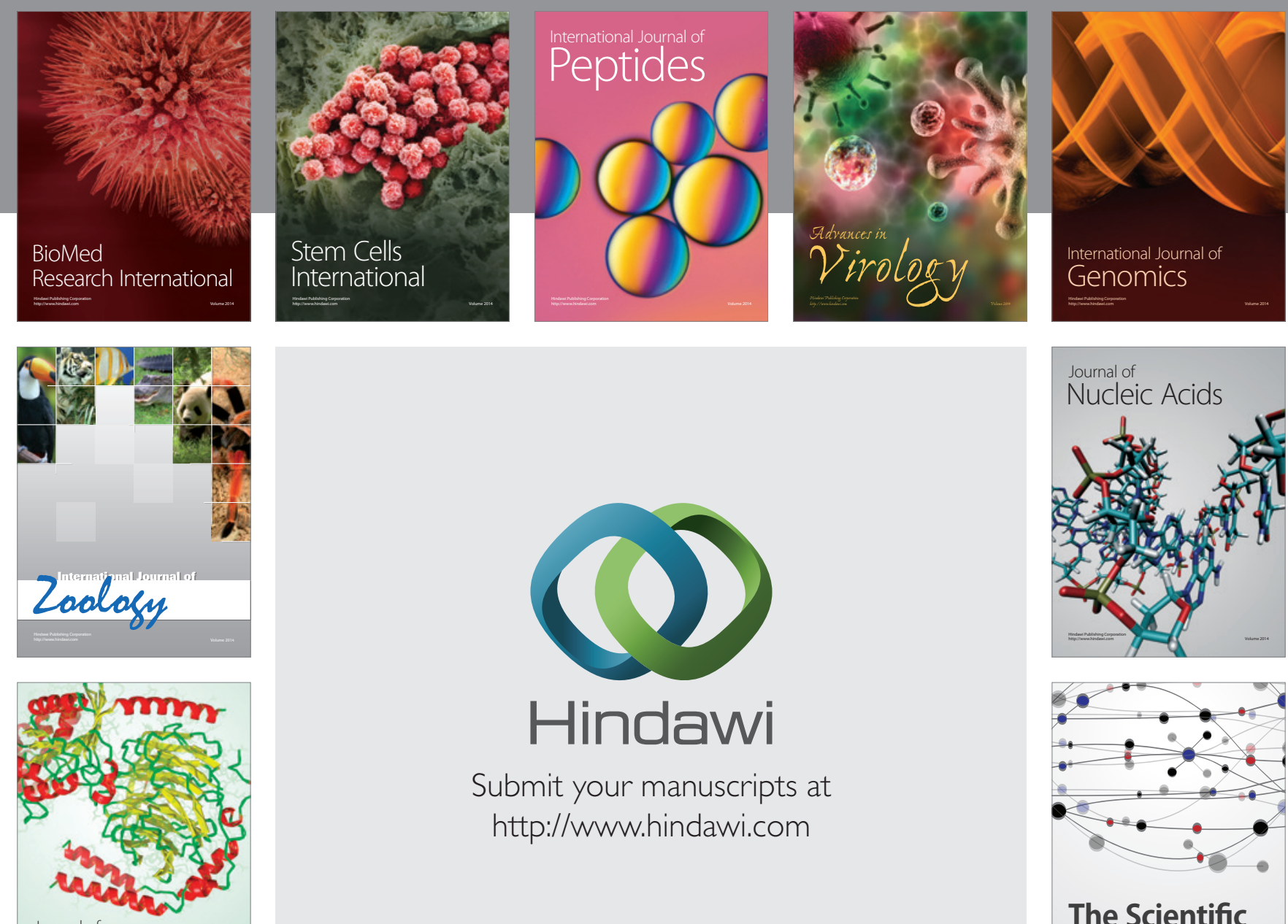

Submit your manuscripts at

http://www.hindawi.com

Journal of
Signal Transduction
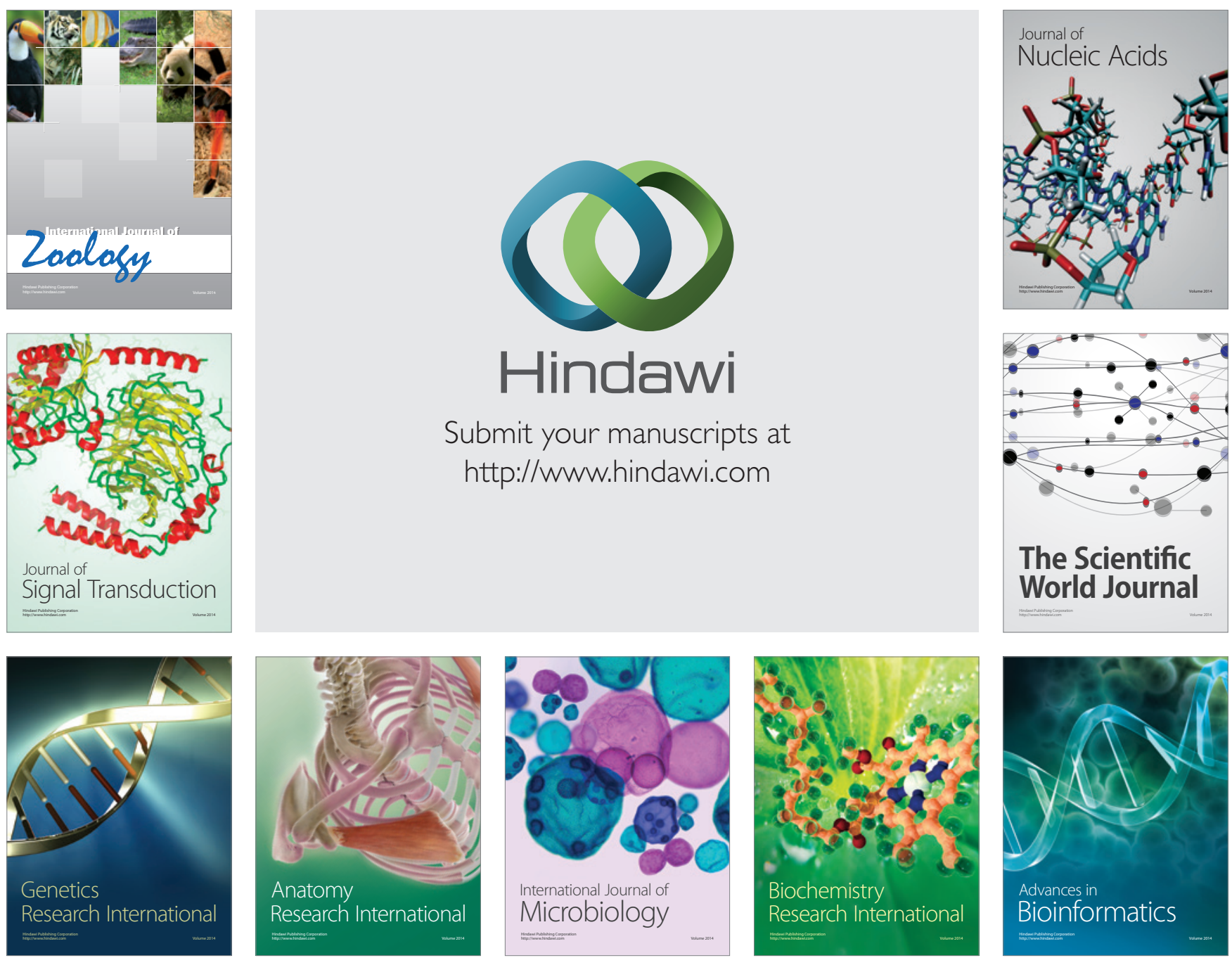

The Scientific World Journal
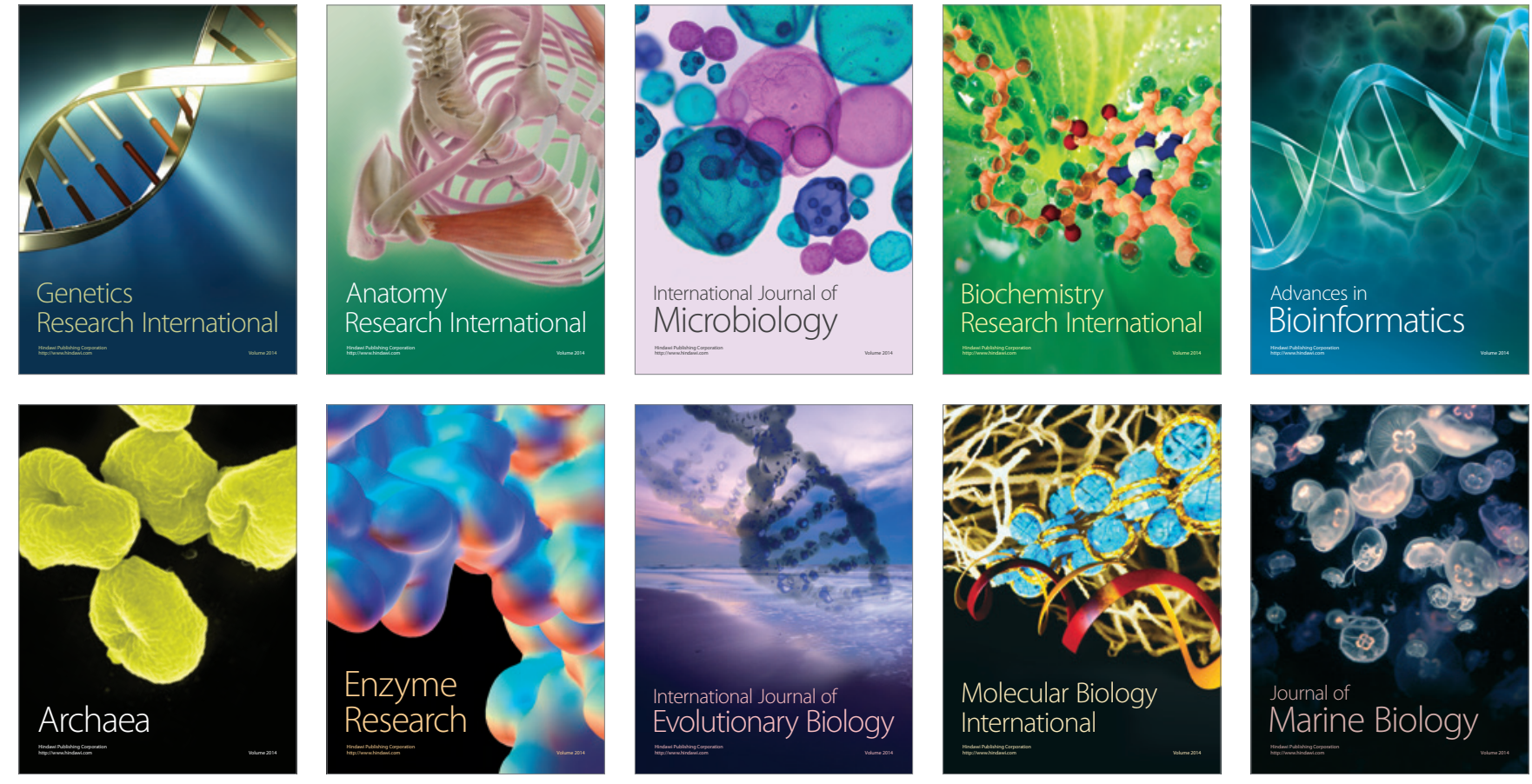